\title{
Placed Appearances: Narrative, the Space of Appearance, Place
}

\author{
By Ali Reza Shahbazin*
}

The space of appearance is defined by the German political thinker Hannah Arendt as a public space, originating in the Athenian polis, where the "I" and the "Other" meet for the possibility of acting politically. This space, in the subjective formulation of some later scholars, is more about citizens "no matter where they happen to be," and less about "the city-state in its physical location," architecture, or urban design. The space of appearance thus conceived is independent of place as the subjective creation of citizens, over against the objectivity of the city. In this study, I argue to the contrary that the space of appearance as a story-telling site achieves place-bound identity through narrativity. My study expands the definition of the space of appearance based on a phenomenological understanding of place as a way that humans feel at home through narrative. I argue that the physical location of the space of appearance is in fact fundamental to its meaning, since place as the setting is part of the narrative.

"We are the children of our landscape." L. Durrell, The Alexandria Quartet (London: Faber and Faber, 1957), 36.

"There's no new land, my friend, no New sea; for the city will follow you..." "The City" by Constantine Cavafy, translated by Lawrence Durrell

\section{Introduction}

"Wherever you go," the Greek statesman Pericles once told his fellow Athenians at a public funeral oration, "you will be a polis." ${ }^{, 3}$ This declaration is traditionally interpreted as meaning that the citizen is the soul of the city. ${ }^{4}$ Consequently, the city as a public realm - as "the space of appearance" - is reduced to mere background or a "static backdrop to action and experience." In this regard, the space of appearance is more about citizens "no matter where they happen to be" ${ }^{\text {" }}$ and less about "the city-state in its physical location,", architecture,

*PhD Candidate, McGill University, Canada.

1. L. Durrell, The Alexandria Quartet (London: Faber and Faber, 1957), 36.

2. Ibid, 201.

3. H. Arendt, The Human Condition (Chicago: University of Chicago Press, 1958), 198.

4. See J. Kristeva, Hannah Arendt: Life is a Narrative (trans.) Frank Collins (Toronto: University of Toronto Press, 2001), 14; P. Fuss, "Hannah Arendt's Conception of Political Community," in Hannah Arendt: The Recovery of the Public World (ed.) Melvyn Hill. New York: St. Martin's Press, 1979. Arendt, The Human Condition, 1958, 198.

5. J. Malpas, Place and Experience, a Philosophical Topography (New York: Cambridge University Press, 1999), 170.

6. Arendt, The Human Condition, 1958, 198. 
or urban design. The space of appearance as a public space where the "I" and the "Other" meet for the possibility of acting politically through action and speech ${ }^{8}$ thus conceived is independent of place. The German political thinker Hannah Arendt put it this way:

The polis [space of appearance, $]^{9}$ properly speaking, is not the city-state in its physical location; it is the organization of the people as it arises out of acting and speaking together, and its true space lies between people living together for this purpose, no matter where they happen to be. "Wherever you go, you will be a polis": these famous words became not merely the watchword of Greek colonization, they expressed the conviction that action and speech create a space between the participants which can find its proper location almost any time and anywhere. ${ }^{10}$

From this point of view, the space of appearance is in fact placeless, as the subjective creation of citizens over against the objectivity of the city. In this study, I argue to the contrary that the space of appearance depends on place, and placebound identity achieved through narrativity. The conception of narrativity for Hannah Arendt is about what citizens do in terms of action (making things happen) and speech (the language of story and poetry) in the space of appearance. As Julia Kristeva says of this Arendtian narrativity, it encompasses "the destinies of life, narrative, and politics; narrative conditions the durability and the immortality of the work of art; but it also accompanies as historical narrative, the life of the polis." "In line with Kristeva's Arendtian definition, life as narrative, I see narrative as stories or explanations that people use to define the way they experience their life and the world. In simple words, narratives say "what happens." 12 When I talk about narrativity I am also talking about the way experience of the world communicated through language (speech) distinguishes narrative from non-narrative. ${ }^{13}$ Language (speech) is one of the main tools for people to share their experience with each other. My paper investigates the relationships between such concepts of narrativity and place on the one hand and the space of appearance in an urban context on the other, building upon Arendt's phenomenological/political reading of public places.

Phenomenological understandings of place and the space of appearance are key in this research, as opposed to approaches such as "environmental psychology" or investigations of place as a "social construct." In the environmental psychology

7. Ibid.

8. Ibid, 199.

9. For Arendt, polis and the space of appearance are overlapping concepts and can even be interchangeable. In other words, the space of appearance - apart being a universal topic - is the core of the polis, the public places such as Agora and Pnyx. I use these terms in a similar manner, but when by polis I am referring to the space of appearance as well, I will make the equation explicit by writing it as polis (the space of appearance).

10. Arendt, The Human Condition, 1958, 198.

11. Kristeva, Hannah Arendt: Life is a Narrative, 2001, 8.

12. Malpas and P. Wake (Eds.), The Routledge Companion to Critical and Cultural Theory (London: Routledge/Taylor \& Francis Group, 2013), 23.

13. C. Baldick, The Oxford Dictionary of Literary Terms (Oxford: Oxford University Press, 2008), 38. 
discussed by geographers Yi-Fu Tuan and Edward Relph, for example, place is approached as subjective. ${ }^{14}$ It is seen as a form of first-person experience a fundamentally psychological construct. A comparable tendency to see place as a subjective social construct can be found in the work of thinkers like the British geographer David Harvey and the French sociologist Henri Lefebvre. ${ }^{15} \mathrm{My}$ argument builds instead upon the phenomenological arguments of philosophers Jeff Malpas and Edward Casey that "place is not founded on subjectivity but is rather that on which subjectivity is founded by place." ${ }^{16}$ From this point of view, place is a condition of consciousness in perception, given with narrative. Primacy belongs to place, rather than to subjectivity. My approach here follows up on Malpas' perspective on "placemaking" as a way humans inhabit the world and feel at home through narrativity involving historical events, rituals and personal memories and fictional stories. ${ }^{17}$ I argue that the ideas of Malpas and Casey are compatible with Arendt's when it comes to the problem of understanding place in the public and political urban frame.

Good architecture is always about place in the sense of a narrative event, and aimed at unveiling a space for poetic "dwelling." 18 Architects are therefore mistaken when they evaluate every new environment as a flat neutral space on a computer. This is especially true given that the public places of the world today are experiencing a kind of crisis of placelessness, due to lies, racism, and violence - in liberal societies as well as authoritarian states. My approach here contributes to the task of addressing this crisis, by recalling the responsibility of architecture and literature as the unveiling of lived place: a narrative, communicative space for citizens to appear and to recognize our fellow humans in all we share, along with all our differences.

For these reasons, the goal of this study is to clarify the meaning and the narrativity of place and the space of appearance. In the opening literature review section, I show that the importance of narrativity in Arendtian architectural scholarship is unhelpfully neglected. Second, in the Polis section, I look at how the space of appearance is constituted and can be understood, in the context of the Athenian polis as a site of storytelling. Third, in the Tópos section, I apply the insights thus gained in presenting my argument that the place-bound identity of the space of appearance is achieved through narrativity.

14. See E. C. Relph, Place and Placelessness (London: Pion, 1976); Y.-F. Tuan, Space and Place: The Perspective of Experience (Minneapolis: University of Minnesota Press, 1977).

15. See D. Harvey, Justice, Nature and the Geography of Difference (Cambridge, MA: Blackwell, 1996); H. Lefebvre and D. Harvey, The Production of Space (trans.) Donald NicholsonSmith (Oxford: Blackwell Publishing, 1991).

16. Malpas, Place and Experience, a Philosophical Topography, 1999, 35.

17. Ibid, 4-5.

18. See A. Pérez-Gómez, "Place is not a Postcard: The Problem of Context in Contemporary Architecture," in Timely Meditations: Selected Essays on Architecture. Montreal: Rightangle International, 2016. 


\section{Literature Review: Action, Speech, and Architecture}

Arendt conceptualizes the space of appearance as the structure of a shared material world and a "space in-between." 19 This in-between world is not simply "nature;" it is the human-made architectural world we inhabit. ${ }^{20}$ Although architectural scholarship on Arendt's conception of the space of appearance has often been of a very high quality (as in the work of British architecture critic Kenneth Frampton, Canadian architecture educator George Baird, and Dutch architecture scholar Hans Teerds), the approach to the public realm always tends to be stylistic, formal, or sociopolitical. ${ }^{21}$

For all of the theorists just mentioned, architecture is mainly about the outcome of human action. Frampton, for example, focuses on defining architecture as action, based on Arendt's definition of "work." He understands architecture as a human work that brings durability into the world and encourages people to engage with the public world. ${ }^{22}$ Frampton rarely emphasizes the theme of the space of appearance in this work. Baird, on the other hand, works explicitly with Arendt's concept of the space of appearance in engaging the architectural debate on public spaces. Baird accordingly acknowledges the importance of human speech (i.e., not action alone) when he writes that action and speech create the space of appearance. Although speech might seem less important than action for architectural discourse, this is not true. ${ }^{23}$ Baird does not actively investigate speech in his study. In his book Public Space (2011), he comes closer to seriously considering issues like speech and theatricality, by studying public spaces through a collection of street photography: heated debate, individuals and crowds, gay rights movements, activist protesting, and political revolutionary actions. Here again, though, speech is subordinated in the end to the visual, in the form of pictures of people talking. ${ }^{24}$

Teerds, like Baird, insists that creating the space of appearance should be the ultimate goal of architecture, but Teerds relies more on narrativity, and on sharing his own virtual and physical experiences of places with the reader. ${ }^{25}$ This narrativity - including notably a moving story of the death of a teenage African American in a gated community - makes his work very convincing. ${ }^{26}$ However, the narrativity involved is largely limited to method, and Teerds rarely brings it consciously into his discourse about the space of appearance. In short, Arendtian

19. Arendt, The Human Condition, 1958, 52.

20. Ibid, XII.

21. See K. Frampton, "The Status of Man and the Status of his Objects: a reading of "The human condition," in Hannah Arendt: The Recovery of the Public World (ed.) Melvyn A. Hill. New York: St. Martin Press, 1979; G. Baird, The Space of Public Appearance (Cambridge, MA: MIT Press, 1995); H. Teerds, At Home in the World. Architecture, the Public, and the Writings of Hannah Arendt. PhD Dissertation. (Delft: Delft University, 2017).

22. Frampton, "The Status of Man and the Status of his Objects: a reading of 'The human condition,", 1979, 40.

23. Baird, The Space of Appearance, 1995, 22.

24. See Baird, Public Space: Cultural/Political Theory; Street Photography, an Interpretation by George Baird (Amsterdam: SUN Publishers, 2011), 49-50.

25. Teerds, At Home in the World. Architecture, the Public, and the Writings of Hannah Arendt, 2017, 606.

26. Ibid, 99. 
architectural theorists tend to focus on action to the detriment of speech, in theorizing the space of appearance. The architectural importance of narrative in public places is therefore wrongly neglected in Arendtian architectural scholarship.

\section{Polis as a Storytelling Site}

In The Human Condition (1958), Arendt applies a philological approach to defining the space of appearance, with reference to the Greek polis. ${ }^{27}$ She looks back to the idea of the polis to locate the origin of public places, and in order to understand the modern crisis of public citizenship. ${ }^{28}$ It is noteworthy here that the German philosopher Martin Heidegger suggests that polis should be understood not just as "city" or "state," but rather as a "site" in a "political geography." 29 Polis is a literally political site for telling the history of being, and since history is a form of story, polis is a storytelling site. ${ }^{30}$ Correspondingly, Arendt defines polis as a narrative site in terms of its basis in "the organization of the people as it arises out of acting and speaking together." 31 These Arendtian and Heideggerian definitions can be combined to identify polis as a site where the story of action needs to be told. In Kristeva's terms, for example, the Arendtian polis is an organizational creation of memory. ${ }^{32}$ Kristeva identifies polis as a place that preserves stories, by insisting on Arendt's interpretation of Pericles' Funeral Oration. ${ }^{33}$ Arendt claims that polis preserves the story of the citizen/hero, so that "those who forced every sea and land to become the scene of their daring have no need of either Homer nor anyone else who knows how to turn words." 34 Polis itself is enough to preserve the heroic story. The Arendtian polis memorializes and monumentalizes through narrative, recalling two of Aristotle's greatest insights: first, that a human is a polis-living animal; and second, that a human is a speaking animal. ${ }^{35}$ Speaking-asnarrating and polis-living are from this point of view interdependent. In this regard, the Aristotelian polis and the Arendtian polis evoke a narrative site for human being. ${ }^{36}$

The narrativity of the space of appearance emerges in the centrality of citizens' action and speech. Arendt bases her understanding of action on Aristotle's Poetics (335 BC), which observes that we understand characters in stories through

27. Arendt, The Human Condition, 1958, 14.

28. S. Dossa, The Public Realm and the Public Self: The Political Theory of Hannah Arendt (Waterloo: Wilfrid Laurier University Press, 2006), 62.

29. S. Elden, "Rethinking the Polis Implications of Heidegger's Questioning the Political," in Political Geography 19 (2000), 407.

30. Ibid, 411 .

31. Arendt, The Human Condition, 1958, 198.

32. Kristeva, Hannah Arendt: Life is a Narrative, 2001, 16.

33. Ibid, 26.

34. Arendt, The Human Condition, 1958, 197-198.

35. Aristotle and P. Simpson, The Politics of Aristotle (Chapel Hill: University of North Carolina Press, 1997), 2-3.

36. N. McAfee, "Bearing Witness in the Polis: Kristeva, Arendt, and the Space of Appearance," in Revolt, Affect, Collectivity: The Unstable Boundaries of Kristeva's Polis (eds.) T. Chanter and E. Płonowska Ziarek. Albany: State University of New York Press, 2005, 118. 
their actions. ${ }^{37}$ When Kristeva comments on Arendtian action and speech, she therefore emphasizes citizens' performed speech as their action in public. ${ }^{38}$ Kristeva understands Arendtian public space as the product of performed action and speech, and a collective diary - a kind of storytelling: a narrative site. ${ }^{39}$ George Kateb, professor of politics, likewise insists on action and speech as important storytelling and performative aspects of Arendtian public space. As he says, without humans there are no stories; we are our stories, as shaped in public spaces. ${ }^{40}$ American philosopher Christopher P. Long also examines Arendtian public space as a public site for transforming time into history/story (memory of action). ${ }^{41}$ In summary, then, the narrativity of the Arendtian space of appearance has already been recognized in the relevant literature.

From a thoroughgoingly Arendtian point of view, the narrativity of the space of appearance is related to space understood as the space in- between things and people. As professor of aesthetics Cecilia Sjöholm cautions, Arendt's notion of narrative should not be mistaken for mere plot, i.e., a sequence of meaningful events. It is emphatically spatial. ${ }^{42}$ On the spatial narrativity of the space of appearance, Arendt herself writes:

Action and speech go on between men, as they are directed toward them, and they retain their agent-revealing capacity even if their content is exclusively "objective," concerned with the matters of the world of things in which men move, which physically lies between them and out of which arise their specific, objective, worldly interests. ${ }^{43}$

Arendt argues that narrativity connects the in-between of things, objects, architecture, and artifacts in the form of a web of stories. The picture is similar to Paul Ricoeur's claim that narrativity is essential in connecting things within a given temporal context, in order to give meaning to those elements. ${ }^{44}$ Michel de Certeau also discusses the relationship between narrative and movement in space in this way: "To narrate is to go through; all stories are a travel report, a spatial practice." ${ }^{45}$ The narrated story, according to De Certeau, is about geographies of action, and is not content to merely recount the action; it spatially performs it within the web of its elements. ${ }^{46}$ For Arendt, this web of elements is where stories

37. Kristeva, Hannah Arendt: Life is a Narrative, 2001, 38.

38. Ibid

39. Ibid, 16

40. G. Kateb, Hannah Arendt. Routledge Critical Thinkers (London: Routledge, 2009), 78.

41. C. P. Long, "A Fissure in the Distinction: Hannah Arendt, the Family and the Public/ Private Dichotomy," Philosophy and Social Criticism 24, no. 5 (1998): 89.

42. C. Sjöholm, Doing Aesthetics with Arendt: How to See Things (New York: Columbia University Press, 2016), 61.

43. Arendt, The Human Condition, 1958, 182.

44. P. Ricœur, "Architecture and Narrativity," (trans.) Eileen Brennan, Robbie Carney and Samuel Lelièvre, Études Ricoeuriennes/Ricoeur Studies 7, no. 2 (2016): 34.

45. M. De Certeau. The Practice of Everyday Life (Berkeley: University of California Press, 1988), 115.

46. Ibid. 
find the power to make a citizen appear. ${ }^{47}$ One of the best examples of such an Arendtian citizen dwelling in the in-between of things in urban public spaces is the figure of Socrates. ${ }^{48}$

The Socratic performance of philosophy happens in the world of things, and the polis (i.e., the space of appearance as found in the agora) provides the stage of public engagement upon which he moves, acts, and makes contact with the world in-between. Socrates' action and speech in public spaces leads to the distinguished self, the heroic act and life story - including his willingness to die a tragic death. In short, Socrates embodies the movement of action and speech in public space. By contrast, the space of appearance in the subjective formulation of some scholars has no objective spatial ground. It is placeless. For instance, Kristeva conceives of the space of appearance as a collective psychic space. ${ }^{49}$ The American philosopher Peter Fuss explicates Hannah Arendt's space of appearance and its significance in a similar way, as what he calls the space of true freedom, concluding that the space of appearance is therefore placeless. ${ }^{50}$ These two interpretations are based on Arendt's interpretation of the line "Wherever you go, you will be a polis," insisting upon Arendt's assertion that the space of appearance is totally unrelated to "the city-state in its physical location," 51 and works the same way "no matter where [citizens] happen to be." 52 However, for other Arendtian scholars such as Hans Teerds and Turkish-American philosopher Seyla Benhabib, the space of appearance is also an architectural topic, and therefore objective. ${ }^{53}$ According to Benhabib, the space of appearance must be architectural given that Arendt constantly refers to space and place. ${ }^{54}$ For Teerds, too, the space of appearance is an objective "tangible space." "55

As Benhabib's formulation indicates, these non-subjective interpretations of the space of appearance come ultimately from Arendt herself. For Arendt, the subjectivity/objectivity of the space of appearance is open-ended. She writes that this space happens in the world-of-things and in the man-made world that simultaneously connects and separates people, as a table does (e.g. an object, architecture, a physical place). The space of appearance does indeed sound quite subjective when she writes that "not Athens, but the Athenians were the polis." Then again, in the footnote she refers to the Athenians as the people of the territory of the city of Athens. Here, at least, she puts the focus on people in place; Athenians are people who are meaningfully placed in Athens. In my own view, Arendt's

47. Arendt, The Human Condition, 1958, 148.

48. See Kristeva, Hannah Arendt: Life is a Narrative, 2001, 42.

49. Ibid, 16.

50. Fuss, "Hannah Arendt's Conception of Political Community," 1979, 122-123.

51. Arendt, The Human Condition, 198.

52. Ibid.

53. Teerds, "At Home in the World," 493.

54. Center for Contemporary Critical Thought, "Hannah Arendt, The Human Condition," YouTube video, 2:15:40, January 30, 2020. https://www.youtube.com/watch?v=4FG8Lynp6Ss\&t $=4743 \mathrm{~s}$

55. Teerds, At Home in the World. Architecture, the Public, and the Writings of Hannah Arendt, 2017, 493.

56. Arendt, The Human Condition, 1958, 195. 
understanding can for such reasons best be described as "intersubjective." It is based on the interrelation between people and place, since the core of Arendtian philosophy is not in the end metaphysical. In its commitment to think both with and beyond Arendt, my study therefore expands the space of appearance based on place, and offers a corrective to the conventional readings of her writing on this topic. In my critical exegesis, which is guided by a phenomenological understanding of place, the physical location of the space of appearance is fundamental. From this point of view, when a given space is associated with narratives such as historical events, rituals, and personal memories and fictional stories, it emerges as a place. Narrative is indivisible from its location, and place as the setting is an essential part of the story.

\section{Tópos $^{57}$ : The Narrativity of Place}

It should be clear by now that this study is in line with the definition of place as a space which becomes part of a narrative, and has an intersubjective link with people. ${ }^{58} \mathrm{Yi}-\mathrm{Fu}$ Tuan highlights, for example, the importance of human speech in the creation of place: place is a function of language's metaphorical and narrative abilities. ${ }^{59}$ From this point of view, place is not just the outcome of material transformations. Place-making can happen by naming a landscape, or by associating it with an origin story, since "naming is the power to call something into being." ${ }^{, 60}$ Malpas argues similarly for the importance of language and narrative in place-making, by concentrating more on narrative as grounded in place. ${ }^{61}$ Narrative as human temporal experience, in his view, is associated with the phenomenon of lived temporality and the qualitative sense of experiencing a place. $^{62}$ For this reason, human memory embodies place as narrative, and place is a space made humanized and humanizing through narrative. ${ }^{63}$ British archaeologist Christopher Tilley similarly stresses the narrativity of a place: "Narrative is a means of understanding and describing the world in relation to agency." ${ }^{, 64}$ In other words, narrative is a means for linking actions and events, locales and landscapes. In simplest terms, place and people reflect each other through narratives and create an intersubjective connection. In Heidegger's terms, the "Dasein" which refers to the experience of being that is peculiar to human beings is based on place. For Dasein, to "be" is to dwell - to be placed. ${ }^{65}$ Place for Heidegger is the kind of

57. Tópos as a Greek word stands for place the way Aristotle or Malpas define it.

58. In all these theories the idea of engagement with place is through language and narrative, and not based on biology or blood.

59. Y.-F. Tuan, "Language and the Making of Place: A Narrative-Descriptive Approach," Annals of the Association of American Geographers 81, no. 4 (1991): 684.

60. Ibid, 687.

61. Malpas, Place and Experience, a Philosophical Topography, 1999, 10.

62. Ibid, 11 .

63. Ibid, 2.

64. C. Tilley, A Phenomenology of Landscape: Places, Paths and Monuments (London: Bloomsbury, 1994), 32.

65. Edward Casey, The Fate of Place: A Philosophical History (Berkeley: University of California Press, 1998), 291. 
"being" in which the characteristically human is grounded. ${ }^{66}$ Like Heidegger, Edward Casey argues that place shapes the self and the self, shapes the place. ${ }^{67}$ For him, place is indivisible from its occupants; place in this sense merges with the things in it, rather than surrounding them. ${ }^{68}$ For this reason, Casey insists that place is a comprehensive, given event. I would add that narrative is not separate from its place and its people. All are givens of an event. If the space of appearance is a space that emerges with narrativity, then it is a place - an indivisible event.

The way the Acropolis Hill was made a meaningful place through narrative provides an illustrative example here. Poseidon the god of the sea challenged the goddess Athena to a contest over the polis. The citizens were to judge and vote. They all went up to the Acropolis across from the Parthenon to present their gifts to the city. Athena won with her olive tree, as the olive later became fundamental to Athenian economy and life. She became the patron of the polis, named after her as Athens. ${ }^{69}$ The Acropolis is therefore part of the story of Athena and Poseidon's contest, as much as the story of Athena and Poseidon's contest is part of the Acropolis. Place is therefore part of the narrative, and narrative is part of the place.

\section{Conclusions}

My goal here was to clarify the meaning of place and the space of appearance, and to highlight their narrativity. I theorized place using mainly the writings of Casey and Malpas, building on Arendt's idea of the space of appearance (and stressing the narrativity). To support this approach, I looked first in the Polis section at how the space of appearance is shaped and understood in the context of the Athenian polis as a storytelling site for political beings. I argued that the space of appearance is a place, and that place-bound identity happens through narrativity. Secondly, in my Tópos section, I concentrated on the definition of place as a space that co-emerges with narrative, indivisible from the things and people who occupy it. I concluded that when the space of appearance has a story to tell it is inseparable from place. For this reason, what the world needs (and what architects are well-placed to provide) is an Arendtian "man-made" narrative public space within which we can appear to each other.

66. Ibid.

67. E. Casey, "Between Geography and Philosophy: What Does It Mean to Be in the PlaceWorld?" Annals of the Association of American Geographers 91, no. 4 (2001): 684.

68. Ibid, 116.

69. W. Burkert, Greek Religion (Cambridge: Harvard University Press, 1985), 139. 


\section{Bibliography}

Arendt, H. The Human Condition. Chicago: University of Chicago Press, 1958.

Aristotle and P. Simpson. The Politics of Aristotle. Chapel Hill: University of North Carolina Press, 1997.

Baird, G. The Space of Public Appearance. Cambridge: MIT Press, 1995. .Public Space: Cultural/Political Theory; Street Photography, an Interpretation by George Baird. Amsterdam: SUN Publishers, 2011.

Baldick, C. The Oxford Dictionary of Literary Terms. Oxford: Oxford University Press, 2008.

Burkert, W. Greek Religion. Cambridge: Harvard University Press, 1985.

Casey, E. The Fate of Place: A Philosophical History. Berkeley: University of California Press, 1998.

De Certeau, M. The Practice of Everyday Life. Translated by Steven Rendall. Berkeley: University of California Press, 2012.

Dossa, S. The Public Realm and the Public Self: The Political Theory of Hannah Arendt. Waterloo: Wilfrid Laurier University Press, 2006.

Durrell, L. Spirit of Place. Mediterranean Writings. London: Faber \& Faber, 1969.

Elden, S. "Rethinking the Polis: Implications of Heidegger's Questioning the Political." Political Geography 19 (2000): 407-422.

Frampton, K. "The status of Man and the status of his objects: a reading of "The human condition." "In Hannah Arendt: The Recovery of the Public World. Edited by Melvyn A. Hill. New York: St. Martin Press, 1979.

Fuss, P. "Hannah Arendt's Conception of Political Community." In Hannah Arendt: The Recovery of the Public World, 252-265. Edited by Melvyn Hill. New York: St. Martin's Press, 1979.

Harvey, D. Justice, Nature and the Geography of Difference. Cambridge: Blackwell, 1996.

Kateb, G. Hannah Arendt. Routledge Critical Thinkers. London: Routledge, 2009.

Kristeva, J. Hannah Arendt: Life is a Narrative. Translated by Frank Collins. Toronto: University of Toronto Press, 2001.

Lefebvre, H. and D. Harvey. The Production of Space. Translated by Donald NicholsonSmith. Oxford: Blackwell Publishing, 1991.

Long, C. P. "A Fissure in the Distinction: Hannah Arendt, the Family and the Public/ Private Dichotomy." Philosophy and Social Criticism 24, no. 5 (1998): 85-104.

Malpas, S. and P. Wake (Eds.). The Routledge Companion to Critical and Cultural Theory. London: Routledge/Taylor \& Francis Group, 2013.

Malpas, J. Place and Experience, a Philosophical Topography. New York: Cambridge University Press, 1999.

McAfee N. "Bearing Witness in the Polis: Kristeva, Arendt, and the Space of Appearance." In Revolt, Affect, Collectivity: The Unstable Boundaries of Kristeva's Polis, 113-125. Edited by Tina Chanter and Ewa Płonowska Ziarek. Albany: State University of New York Press, 2005.

Pérez Gómez, A. "Place is not a Postcard: The Problem of Context in Contemporary Architecture." In Timely Meditations: Selected Essays on Architecture. Montreal: Rightangle International, 2016.

Relph, E. C. Place and Placelessness. London: Pion, 1976.

Ricœur, P. "Architecture and Narrativity." Translated by Eileen Brennan, Robbie Carney and Samuel Lelièvre. Études Ricoeuriennes/Ricoeur Studies 7, no. 2 (2016): 31-42.

Sjöholm, C. Doing Aesthetics with Arendt: How to See Things. Columbia Themes in Philosophy, Social Criticism, and the Arts. New York: Columbia University Press. 
2016.

Teerds, H. At Home in the World. Architecture, the Public, and the Writings of Hannah Arendt. PhD Dissertation. Delft: Delft University, 2017.

Tilley, C. A Phenomenology of Landscape: Places, Paths and Monuments. London: Bloomsbury, 1994.

Tuan, Y.-F. Space and Place: The Perspective of Experience. Minneapolis: University of Minnesota Press, 1977. 
